\title{
Celtic Countries From the Perspective of Polish ROMANTICS AND EXILES
}

\author{
KATARZYNA GMEREK
}

\section{Stanisław Egbert Koźmian in Ireland and Scotland}

It happened in 1844, in Abbeyfeale, West Limerick, on the way from the Lakes of Killarney to Dublin. Stanisław Egbert Koźmian, a Polish writer, temporarily based in London as a political émigré from Russian Poland, travelling in mixed company made up of Irish and English friends. The gentlemen amused themselves by guessing at the identity of a poor passer-by. The outlandishlooking, barefoot wanderer was carrying a heavy pack of books; it was difficult to guess who he could be and what he was up to. Was he a some exotic Other, an Indian perhaps? Koźmian had his own idea: "He was the immortal O'Donoghue, it seems to me" (Kozmian n.d.: 10), later recorded in his unpublished travel journal.

Koźmian was among a small number of Poles who visited Ireland in the nineteenth century and left accounts of their visits. He learned the legend of O'Donoghue while sightseeing in Killarney, and remembered it in his own way. O’Donoghue, popularly called O’Donoghue Mór of Ross, was a historical person, about whom many legends were told, especially about his apparent magical departure from this world and immortal life under the waves of Lough Leane. Modern folklore researchers find in the O'Donoghue stories a mixture of local and international motifs (Ó hÓgáin 2006: 395; for a nineteenth century account see for example: Crooker 1853: 31). O’Donoghue was a sorcerer who, according to some legendary accounts, disappeared after misusing his magical powers. It is possible that Koźmian was captivated by the similarity between the Irish legends and Polish legends about the sorcerer Twardowski. According to the nineteenth century tales the Irish chieftain still lived in a palace under Lough Leane, returning each year, on May eve - there is Thomas Moore's poem about this, and Koźmian, who loved Moore, undoubtedly knew it (Moore 1823: 197).

O'Donoghue made his second appearance in Scotland, near Aberfoyle, when the Pole was travelling across the Pertshire Highlands. It must be regretted that Koźmian never elaborated on this subject. Nevertheless, the short entry in his note book can tell us something important about his attitude to Ireland and Scotland. As one of the first Polish Hibernophiles he believed that in the more distant areas of the island "a spirit of the ancient Irish rough simplicity lives, and the people are ipsis hibernicis hiberniores" (Koźmian 1845). It is clear that from 
this perspective O'Donoghue belonged to the spirit of ancient Gaelic past. Koźmian was not erudite as far as Celtic culture is concerned. When describing the isle of Iona, he said that the crosses had 'rings encircling four arms' and did not use the term 'Celtic cross'. But he was clearly interested in local culture and repeatedly questioned local informants. In Ireland he had written down the English words of the song Crúiscín Lán and noted that this version had many strophes and included a list of the names of drinkers and listed many names of drinkers, including Daniel O'Connell, whom Koźmian personally knew and admired (Koźmian 1862: 2). He had met the famous Killarney piper Gandsay, who played for him a tune called the Killarney Fox Hunt. But he did not manage to discuss the Irish language. In Scotland he was on his own, or for some time with one other Polish traveller, and his interest in Gaelic was pursued forward.

When travelling on a stage-coach across Pertshire Highland, Koźmian spent some time in the company of Rev. Dr McLeod and his young son. To his amasement, the pastor conversed with the child only in Gaelic. Apart from that, during their long journey Koźmian and McLeod had an interesting discussion on a number of subjects, including local history, place names and legends. It is not possible to ascertain who exactly McLeod was, although we can possibly identify him with the John McLeod Campbell (1800-1872), a learned Gaelic-speaking pastor. McLeod boasted to Koźmian that he had delivered a sermon before Queen Victoria and was invited to dine with her in Blair Atholl on the previous Sunday. By chance, the Queen happened to be in Scotland at the same time as Koźmian in 1844.

It might have been Reverend McLeod who gave to Koźmian not always fully accurate information about local place names. If Ben Lubnaig actually means Crooked Lake, Ben Ledi does not mean the Hill of God, however, it was believed to be so because of a misinterpretation of another minister, Doctor James Robertson. The intriguing association of the village of Immirioch, now difficult to locate, with Niniveh might have something to do with another assumption of a nineteenth century clergyman - it was believed that pagan rites associated with Baal were performed on the summit of Ben Ledi, because of a link with an ancient Celtic god of the same name. Somehow the learned pastors projected the imagined Biblical world into their own Scotland. A local teacher was another source of information on Gaelic for Koźmian. They met presumably in Glengyle, because Koźmian noted that this was 'Rob Roy's place of birth'. At times the almost stenographic quality of his notes makes it difficult to understand the full story. For example, Koźmian includes the following passage:

Night at the teacher Stewart's home. A dictionary. An old bard from Oban, a Roman Catholic; gone by night on foot to visit the old graveyard in Glenfinlass. 
He did not say if the bard was dead and buried in Glenfinlass, or, alive and well, and dining with him, or maybe the teacher Stewart and the old bard were the same person. Koźmian was a Romantic, and visiting a graveyard by night would be to his taste. And the fame of Glen Finglass (modern name) was widespread thanks to a poem by Walter Scott. The teacher showed him a Scottish Gaelic dictionary and told local stories. The Pole noted that 'Came-hai-she' - meant 'how are you' (Ciamar a thà sibh) and 'Arran ska'z - 'bread and cheese' (Aran 's caise) (Koźmian n.d.: 20).

\section{The travelling clan of the Czartoryskis, and their library}

It might be difficult to explain the roots of the Polish interest in matters Celtic during the early Romantic period without going back in time, and mentioning the aristocratic and once mighty Czartoryski clan, their fascinations, and their cultural patronage (Aleksandrowicz 1998, Gołębiowska 2000).

The Princes Czartoryski Library in Puławy (Russian Poland) seems to have been the primary local source of information on Celts among learned readers in Poland before 1831. Puławy as a cultural centre was once called the 'Polish Athens' (even if this was an exaggeration, the place was exceptional). The Czartoryskis had a passion not only for collecting books, but also for sharing them with the reading public. The pre-1831's generation of Polish literati were able to find there both recent and older books published in Scotland, Ireland and Wales. The Czartoryskis had Scottish roots (there was a seventeenth century connection with Gordons and Campbells, cherished by the Campbell of Argyll family who frequently met with Czartoryskis). This fascination with the country of their ancestors helped to spread the cult of Ossian in Poland, however, another historical factor was also of some importance, as is clear from the growing popularity of Macpherson from the time of the third and final Partition of Poland (1795). The reception of 'Ossian' varied in European countries: it is known that Napoleon treasured this poetry because it glorified battles and warriors; however, Polish readers recognized in it, among other things, the melancholy of their own decline. They found in Macpherson the image of the lost Arcadia of independence and glory, painfully contrasted with a sad contemporary reality. Macpherson's strange 'translations' also carried the idea of a special kind of poet, a bard, commenting from an exalted position on developments within the society, but without the requirement that he apply classical rules to his verse. The first fragmentary Polish translation of 'Ossian' was published in 1790; subsequently many Polish poets at the turn of the nineteenth century tried to imitate not the form, but the atmosphere and style of Macpherson; with the term 'bard' being frequently used at that time. At least two Polish translators of Macpherson were connected to the Czartoryskis, Franciszek Karpiński and Franciszek Dionizy Kniaźnin, although the first full translation was not published until as late as 1838. 
When visiting Britain, Izabela Czartoryska (1746-1835) and her son Adam Jerzy (1770-1861) spent the year 1790-1791 mostly in Scotland, where Adam attended lectures in the Edinburgh University and his mother did a lot of sightseeing. We have her notes from a journey to Scottish Highlands, indicating that the Princess was curious about 'real' Ossianic songs, asking people to sing them to her. Though she did not know any Gaelic, her impression was that the songs 'sounded true', simply because her heart informed her about this. Even if her approach seems to be somewhat sentimental, her interest persisted. The princess wrote naïve but moving essays about Scotland, to accompany some artifacts she brought from that country to Poland. They were read in manuscript by many visitors in the Domek Gotycki (Gothic House), a public museum maintained by Czartoryskis in Puławy, apart from the Library.

Karol Sienkiewicz, at that time the new librarian of Princes Czartoryski, visited Scotland and Ireland in 1820 and 1821. He was there to study library management, and to purchase books (Sienkiewicz 1953).

He had a disheartening experience in Trinity College Dublin, where an elderly librarian did not even allow him to see the manuscript catalogue; the senior librarian maintained that his old age and poor health would not allow him to go up fifty-something steps to the catalogue. In the autumn 1820 Sienkiewicz toured the Scottish Highlands. His response to Gaelic culture was complex. While watching a Scottish Highland dance, he enjoyed it and thought that both movements and rhythm were similar to the Ukrainian folk music. But he did not like the sound of the large Scottish bagpipes, feeling that the sound was too loud and harsh. The music of Irish uillean pipes was more acceptable, and he even wrote home that the instrument was 'elegant', and should be imported to Poland, where it could be used instead of reed organ in chapels. Sienkiewicz had mixed impressions about fellow-travellers on the road. When once he encountered a group of Highland girls singing a Gaelic song, he called them (perhaps recalling Macbeth) 'real witches'. Sienkiewicz admired Macpherson and Scott, and like many other Polish visitors to Scotland perceived the land through the lens of literature. One may smile at his attempt to make a translation from Macpherson, when sitting under his umbrella on the banks of Loch Lomond in the rain. This work has remained in a manuscript. Nevertheless, the translation of The Lady of the Lake that he made in Edinburgh was printed and became very popular. Sienkiewicz did not seem to need any human company when in the Highlands, the landscape and its atmosphere was everything he needed believing it was possible to have a communion with nature without intermediaries. He was rather upset about the curiosity of the locals. Even when they spoke English, Sienkiewicz did not want to converse with them, he preferred the company of his own thoughts. It seems an extreme case of a purely literary interest in Scotland, deprived of any social or historical dimension. In a way, the traveller mentally never left Poland. 
Prince Adam and his librarians purchased many books in Britain, but because of the war damages incurred in the nineteenth and the twentieth centuries it is impossible to ascertain their exact number. However, the modern Princes Czartoryski Library in Kraków still obtains some interesting items acquired during that time. Among these, for example, are the eighteenth century Histories of Ireland by MacGeoghean and Leland, and seven related (1799-1802) brochures about the Irish Act of Union of 1800, as well as the seventeenth century Histories of Scotland, and Scottish travel descriptions. To these need to be added two eighteenth century antiquarian works: Charles Vallancey's essay on the history of Irish language and John Toland's Miscellaneus Works, with his study of druids (Toland 1747) and also containing a separate study by 'Mr Jones' of Welsh bards. Adam Jerzy Czartoryski's writings provide an example of how Polish readers might have been influenced by these compositions. As a young man, in 1795, after the failure of Kościuszko uprising, he wrote a poem 'Polish Bard', filled with Ossianic melancholy, but with even more resemblance, perhaps, to Thomas Gray's poem about a Welsh bard, cursing an English king (Gray 1757). In the Polish poem the accursed monarch was Catherine the Great. Later, in his unpublished educational treaty On Knighthood the prince devoted great attention to the Welsh, emphasising the role of bards.

It is difficult to find in Europe a similar place, where inside such a limited area and in this [small] piece of ground one nation, one spirit, one language.

(Czartoryski n. d.)

It is apparent that the author wished to encourage his compatriot poets to imitate the Welsh in respect of their role in preserving the national culture in the times when the independence had been lost. This work remained unpublished, but Czartoryski was a long-time official curator of the Vilna educational district, and had a big influence over school curricula in the Polish-Lithuanian and PolishUkrainian areas. He was by no means a dissident at that time, but a statesman and aristocrat, who was well-received in St. Petersburg. He even served as Russian Foreign Minister in Napoleonic times (1804-1806). Many Polish commentators regarded him as Anglophile, who wanted to create an imitation of British educational and legal institutions in Poland. Taking into consideration his interests and unpublished works, it can be argued that being both a statesman and an educator, he had a dream that Poland might form an union with Russia, while preserving its autonomy in legal and educational matters, similar to the Scotland's connection with England. In view of many books on the Irish Act of Union he had in Puławy, he seems clear he was highly interested in the process of managing ties between the capital and the province; however, it is unlikely that he wished Poland to be in the position of Ireland of that time. The vision eventually turned out to be unrealistic, out of tune with the popular mood in Poland and political 
traditions of Russia. Inevitably, during the 1830-1831 uprising against Russia Czartoryski made a tough choice that left him a political émigré forever, he was sentenced to death in absentia, and his property confiscated. With most of his family he moved to Paris; the part of the library that survived burning and plundering was transported to Paris, and today is a part of the National Museum in Kraków.

During the time when the library existed in Poland, a circle of people became acquainted with its holding of 'Celtic' books. Readers included the Prince, Princess Isabella, and Dr Krystyn Lach-Szyrma, who was a tutor to Czartoryski's sons, as well as the librarian Karol Sienkiewicz, who was a historian. Stanisław Egbert Koźmian was a member of a noble family, containing many poets and writers, from the Lublin area. Members of the family are frequently included among the 'Puławy circle' and Stanisław Egbert can probably be considered as belonging to the last generation of Puławy-influenced writers. The older Julian Ursyn Niemcewicz, one of the Polish translators of Macpherson and Moore, belonged to the circle too. ${ }^{1}$

\section{Slowacki the Druid}

Another Polish traveller, who developed some interest in Celtic matters, was Juliusz Słowacki, educated first in the famous Krzemieniec high school (today Kremenets in the Ukraine, before 1831 it used to be inside the Vilna educational district), and then in the Warsaw University. He was interested in the history of the Celtic lands from a young age. A teacher's son, as a boy he learned English in a usual way, with the help of a private tutor, Dr McDonald, who was Scottish, and with whom he read Thomas Moore and Walter Scott. It is probably thanks to this connection there were no historical inaccuracies in his early drama, Maria Stuart. All his life Słowacki read passionately, and later developed a taste for mystical, oriental and somewhat exotic readings in foreign languages. Unfortunately we do not possess a full list of his readings, which would be of considerable interest. After 1831 he emigrated and lived mostly in Paris. From time to time he used Celtic historical and mythological motifs in his drama and poetry. His most famous work of this kind was the dark, mythological drama Lilla Weneda. The play, which is shaped like a Greek tragedy, was subjected to many interpretations, from a typical nineteenth century discussion on the origin of Polish people, to more wide ranging reflections on the meaning of poetry in history. The main symbolic accessory of the drama is the golden harp of the Venedi. It is difficult to be sure of the origin of this symbol as used by Słowacki. Together with many educated Polish readers at his time, he adored Thomas Moore's poetry, and these volumes of Irish Melodies contained a lot of information about Irish history,

\footnotetext{
${ }^{1}$ It should be added, although this is a topic for discussion elsewhere, that a highly popular volume of lyrical poetry entitled Historical Songs of the Poles bears marks of strong influence by Scott and Moore (Niemcewicz 1816).
} 
mythology and culture, based on the state of knowledge in the early nineteenth century in the footnotes. In addition, Słowacki was familiar with the French history of literature, Histoire littéraire de la France avant le XIIe siècle..., by Jean-Jacques Ampère who, unable to provide details of the old Gaulish literature, wrote an account of other Celtic literatures instead (Ampère 1839: 24). This book emphasised the socio-political role of the bard in Celtic society, discussed the hierarchy of the druids, the vates and the bards, but also provided information of Irish wandering harpers and their declining popularity in modern times. He wrote on the harp as the symbol of Ireland, and on the role of poetry in preserving national identity. Juliusz Słowacki then imagined a tribe of Celtic Venedi in ancient Poland, with a druid-king Derwid (derwydd is the Welsh word for a druid) as their monarch, and a Greek choir of minor harpers-druids commenting the tragedy. The cultured Venedi are conquered by a tribe of Lechici, a wild mixture of vagabond Slavic and Nordic tribes. Lilla Weneda could be described as a poignant Romantic drama of invasion and hopeless struggle. The symbol of an enchanted harp, taken apparently from old Irish tradition via Ampère and Moore, is treated in an almost revisionist manner. The Venedi believed that the harp could save them, but they lost it and it was never recovered. Is that, Słowacki asks, why they lost their spirit, too? Did it make them psychologically weak, so they might be better off without this instrument? Was the harp really magical - this question implies another one: is poetry really that important, does it have the power to save anything? Basically, the author's starting point were anecdotes from Byron about ancient Gauls fighting against Romans and also, probably The Martyrs by Chateaubriand. The harp as a symbol of poetry and of the poet, especially in his role as a prophet and leader, has additional cultural associations, most obviously with the Bible. However, by their own admission, the Polish Romantics linked it to Macpherson or Thomas Moore.

Walter Scott needs to be mentioned at this point. Multiple titles by Scott were published in pre-1831 Poland, indicating a level of popularity which was never subsequently repeated. The wealth of antiquarian footnotes and endnotes in these books enriched popular knowledge on Celtic cultures. Unfortunately there were limits to the knowledge that could be harvested from such books. Firstly, the discipline of Celtic studies did not exist in Europe at that time, and various works published in Britain or Ireland were largely of an antiquarian character. Secondly, the Polish and other non-Celtic readers of the Romantic period had only an access to sentimental or Romantic sources written in English from the Celtic countries. Both Macpherson and Moore created their poetry under difficult historical circumstances, which gave a melancholy resonance to the music produced on their respective harps.

Even for the reader whose knowledge of Celtic literatures is dependent on translation, it is clear that the meaning of the harp in English-language poetry was not identical with that contained in older poetry in the vernacular languages. It 
was not, of course, completely different; it is possible, for example, to make a comparison with the Irish mythological story about the enchanted harp of Daghda that played three kinds of music: these of sorrow, of joy, and of slumber.

Modern poets very often played only the strain of sorrow, and this was copied by their non-Celtic imitators. In agreement with other non-Celtic readers, the Poles could not have fully appreciated the fact that the harp used to be a symbol of a glorious past, when bards and musicians performed during great feasts in the presence of their generous patrons, and not an icon of failure, desolation and death. It may well be that the sad harp of Moore was invested with a certain irony in this context, which Polish readers and writers were unlikely to appreciate. Being themselves in a difficult position, as bards of an oppressed country, they found sorrow congenial to their feelings and immediately put the mantle of Ossian on. The very harsh conditions to which Polish literati were subject in the nineteenth century, in particular the censorship and draconian punishments for subversive publications, resulted, among other things, in considerable emigration.

Hence, the Polish émigré poets were given an unusually significant role in the Polish nineteenth century culture, a phenomenon that was not mirrored in any Celtic country. It may even be proposed that the Celtic fascinations of the Czarotryskis circle contributed to the growing cult of the Romantic bard in Poland.

In addition to the noun 'bard', a different word, wieszcz, emerged in Polish pre-1831 poetry, and was used more frequently after 1831 . Wieszcz means more than a Gaelic file, but rather points to the role of a poet endowed with prophetic functions. The origin of the word corresponds to the Latin vates, and the Irish fáidh; the connection between the words vates and fáidh was suggested by both Toland (1747) and Ampère (1839; see also MacKillop 1998: 181, 385). Even when very few Poles believed in the impossible theories of Słowacki or his friend Lewestam (1841) on the Celtic origins of the Poles, the harp became a significant cultural symbol. It was a symbol of the bardic voice of the poet, who undertook a complex role of one of the pillars of community: not only a recorder of history, but also a spiritual leader and prophet. Returning to the drama Lilla Weneda, it seems that for Słowacki the only magic of the Venedi harp was in the heads of the unfortunate tribe. As the magic of the harp never really worked, Romantic irony is entwined in the drama with Romantic sadness and echoes of Greek tragedy. One of the poet's disciples from the turn of the century, Maria Konopnicka, treated the harp of Venedi without intellectual distance or irony. Some of her poems employed motifs of a 'druidical harp' as a symbol of the Polish national poetry, and even Adam Mickiewicz's dead body was compared to the golden harp (Konopnicka 1915: 143).

The late writings of Słowacki were highly cryptic, based on a mixture of Christian and Oriental religious influences that might have been of interest to 
Yeats. Słowacki spent two holidays in Pornic, Brittany, 1844 and 1845, at a time when he was already very ill. Since the time of the revolution, Pornic had become attached to another administrative region and was therefore separated from the rest of historical Brittany (now Loire-Atlantique).

A local dolmen was of particular interest to him. At the outset, the poet was bitterly disappointed with Pornic. As was the case with many other travellers to Celtic countries, he had high, if unspecific, hopes when going there; he expected local people to entertain him with Breton fairytales and legends about the dolmen. Unfortunately, he found there an ordinary fishing village, locals being occupied with their everyday jobs during the day, and socialising at night. The Polish poet lamented that 'Voltaire's spirit prevails in taverns' (Słowacki 1915: 202). One could speculate what he meant by this, perhaps, the lack of poetic and spiritual dimensions in the conversations he overheard, with no interest displayed in Breton traditions. It may be that people talked only in French. But the Polish poet eventually found the Other Side drawing on his inner powers: during his long walks along the sea-coast he entered "communion with Druidic spirits". The poet was very pleased to find at least one living Breton with some interest in local traditions. It was a 10 year old shepherd girl. She told him about the crowned serpents that were supposed to be sleeping under the local dolmen. Słowacki's poetic imagination had built a new legend about the adorable girl - he adored her, and presented her as an incarnation of a Druidic soul, unable to leave the sacred stones. She was immortalised in a poem 'To a Little Shepherdess Sitting over the Ocean at the Druidic Stones'. It can be recalled that the English poet Wordsworth similarly adored a shepherdess, a girl from the Scottish Highlands. But the Pole had gone further, because the Englishman adored his teenage Scottish Highlander only for her innocence and beauty, and did not attribute any magical powers to her (Wordsworth 1807: 23).

It may be worth mentioning that fifty years after the death of the poet, a book entitled Julisz Stowacki the Druid (Jellenta 1911) was published. Jellenta was a literary critic and journalist who had no knowledge of Celtic culture. His concept of druid was based on a vague idea of a perfect image of a Polish poet, combining literary and spiritual dimensions with a sense of leadership for Poland.

We can observe here the same pattern as in the writings of Koźmian: a Polish writer visits a Celtic land, with his imagination full of Romantic poetry, and deeply interested in local traditions. When he could not find an anticipated otherworldly dimension, he simply imagined it (or assumed, as Princess Izabela 'found' her 'Ossian' without even understanding the Gaelic of her distant ancestors). As for the two O'Donoghues of Koźmian, they were most probably local teachers, but he had chosen to see an immortal hero in them. We may smile, but one can see a symbolic connection between a Celtic-speaking teacher in the West of Ireland or the Scottish Highlands, and O'Donoghue, as both belonged to a distinct local tradition that was already in decline. Koźmian was a very sensitive 
reader. He was able to perceive unique cultural features lying at the basis of Irish and Scottish stories and legends, even though he grasped the meaning of the latter through the medium of English.

As for the little Breton girl of Pornic, in Słowacki's eyes she was another 'O'Donoghue', a medium through which he attempted to connect to the past. Słowacki thought of her as a kindred spirit, who he believed had already been through many incarnations, and was able to communicate with other similar beings in a mystical way. He learned about druids from the Ampère's book, who described the system of druids, bards and prophets as Celtic intellectual elite, and emphasised the interconnection between poetry, religion and knowledge in the Celtic world. This idea of fusion between all kinds of human creativity appealed to Słowacki and fuelled his imagination. The poetical treatise he was writing at that time, Genezis from the Spirit, was ultimately filled with Atlantic imagery (Słowacki, n.d.).

\section{The Polish émigrés}

There were more other travellers from Poland. Krystyn Lach-Szyrma, already mentioned here before, might be included in the academic group. Although his knowledge of Scotland and Ireland was large, he never indulged in Romantic visions. His knowledge was in part typically antiquarian, as were his lectures - for instance, he claimed that ancient Celts might have adopted harp music from the Scythians, who he believed undoubtedly were Slavonic (Lach-Szyrma 1829). This was his contribution to the Hyperborean theory (Bridgeman 2005), discussed also by John Toland in the book we mentioned (Toland 1746), although Toland and Lach-Szyrma located the Hyperbora in very different places; the first in the Hebrides, the second in Eastern Europe. One of Szyrma's arguments appears particularly weak: he claimed that Scottish and Irish Gaelic songs resemble Slavic ones, because of their tonality and emotionality.

Later, after the collapse of the Polish uprising of 1830-1831, many émigrés arrived in France, Britain and Ireland. Lach-Szyrma was among them, and because of his political responsibilities settled in England. He married, and became a father to Władysław Lach-Szyrma, the clergyman who contributed to the Cornish Revival (Hale 2006: 1105). It is not difficult to see a connection between Krystyn's Scottish and his son's Cornish interests. However, Władysław was not an émigré, but a Briton of Polish descent, and we will have to omit his story.

Most political émigrés were ex-army officers, and not the men of letters or scholars, and their interest in local cultures was limited. Mostly, the educated ones were active in the Polish political lobby, which left them little time for other interests. Jerzy Ręczyński, for instance, spent fifty years teaching engineering and languages at Foyle College and Magee College in Derry, but though he was a prolific writer, he was not especially interested in local matters (Roberts, 
Fergusson 1988). He wrote a grotesque play Rymotwór (1854) about the Halloween, implying, however, the recent political developments in Poland of 1846. Ręczyński's numerous unpublished letters mostly concern Polish political issues, or his own work as an engineer and as an amateur Biblical scholar. He was not interested in Irish or Scottish history and culture. Jan Bartkowski was his fellow-teacher in Derry, where he spent ten years, mainly teaching languages (Bartkowski 1967: 297). His diary mostly offers personal recollections of an exofficer, a lonely émigré, struggling hard to make relationships in an Englishspeaking environment. His social observations were limited to the group of local Protestant teachers, with whom he could not feel any religious affinity, because his Polish Protestantism was somewhat different from theirs'. Rumours that he could have been a crypto-Catholic upset him. He felt alienated and eventually left for France. Both Bartkowski and Ręczyński integrated with local communities on a very basic level, but never really felt fully at home.

Throughout the nineteenth century, Brittany was becoming increasingly popular as a holiday place for people living in France, including the Poles. Most visitors looked at the land and its people from the perspective of an uninterested tourist. There were, nevertheless, Polish Romantics, who might have never seen any Celtic land, but employed various Celtic mythological elements in their writings or those taken from the literature of Celtic countries. The Polish translator of Hersart de La Villemarqué's Barzas Breiz, Lucjan Siemieński, probably never visited Brittany, and was driven to this work by his interest in European folk literature (de La Villemarqué 1842). In the characteristic manner of Romantics, he used Slavonic vocabulary elements and imagery in the translation of Breton poetry. As a result, the Siemieński's Breton lays sounded somewhat Polish. This tendency to domesticate the Celtic material was evident even in some Polish translations of Macpherson, especially evident in the use of folklore phrases and motifs. Translators probably wished to avoid dressing the Scots up in the national costumes, but if there was some justification for this approach in the case of Breton songs, it was different in the case of Macpherson, and as a result, such attempts were somewhat 'folksy', characterised by quality absent in the original.

It is not known whether Tomasz August Olizarowski, a Romantic who frequently employed Celtic subjects in his poetry, visited any Celtic country. He lived for ten years in London, and it is probable that the translated literature and mythology was all he knew. His works have their settings in many countries. From his Celtic-oriented titles we know: the unpublished Etoryx, a drama on Vercingetorix, the leader of a revolt against Rome, The Maids of Erin (published 1857, the idea conceived probably after 1848), a drama on a Polish-Irish relationship, with inevitable anti-colonial accents, and a poem Streams of Emrys, employing some elements from Welsh legends mixed with Classical mythology (Olizarowski 1852: 27; see also Gmerek 2007). Another émigré who lived in 
England and France, Leon Ulrich, known as a good translator of Shakespeare, published a long epic poem on Turlough O'Carolan (L. U. 1856: 206). The author treated the famous harper as his alter ego, portraying him as an artist suffering from alienation. Ulrich's knowledge of Irish history and realities seemed to have been limited; most probably the source for this poem was Bunting's volume The Ancient Music of Ireland published in 1796, and re-published in 1802 and 1840.

\section{Conclusion}

In this piece on the Polish Romantic travellers confronted with Celtic cultures and countries, I have tried to show the way they reacted and how their imaginations worked. Probably some of their reactions were not different to those of all other Celtophiles. The special role of the Czartoryskis cultural patronage needs to be highlighted. It would be impossible, naturally, to discover every reader from this circle, as library in Puławy was public at the time. It is a pity that many of these books were typically of antiquarian character, written before the establishment of the Celtic Studies as an academic discipline, for a simple reason that such an opportunity (to improve the level of knowledge on the Celts in Poland) had never been repeated. After the Celtophile Czartoryskis emigrated, their remaining funds were spent for more practical (yet less pleasurable) purchases. In the nineteenth century Poland, nobody ever attempted to gather so many books about Celtic history and culture again, even after the emergence of Celtic Studies as an academic discipline later in the nineteenth century. The predictable result was that, with time, knowledge of Celtic cultures diminished among the Polish writers. The literary revival in early twentieth century Ireland, associated with Yeats and his contemporaries, did not elicit widespread reaction from Polish librarians and academics. This failure to respond to new developments in Ireland is probably to be explained in terms of the economic and socio-political conditions in the divided Poland of that time.

The distinct feature of the nineteenth century Polish culture was the manner in which it was deeply affected by the course of the nation's history. One of the many negative results of the partitions at the end of the eighteenth century was that a large number of important writers moved abroad, as well as that their relations and impressions were affected by this emigration. Being a political émigré was not always helpful in so far as the exploration of new cultures was concerned, both from the point of view of the psychological trauma of being away from home and of various everyday constraints. However, in lots of instances such Poles in exile were able to comprehend the reality similar to theirs in a more obvious way, and in some cases, they sought new perspectives for themselves.

Koźmian and Słowacki came to Celtic lands, entertaining great expectations, motivated by their prior knowledge of Celtic poetry. The power of their dreams was so strong that when they could not find what they had been looking for, they created this in their own mind. The young librarian Sienkiewicz 
visited Ireland and Scotland, but preferred to avoid interaction with people on the road. Lach-Szyrma visited Scotland which he described with sympathy and accuracy, but without the imaginative characteristics. In spite of these limitations, various creative writings and reliable translations resulted from these three voyages.

Some émigrés resided in beautiful parts of Scotland and Ireland not paying attention to the unique beauty of their new homelands. Some writers made translations or employed motifs from Celtic literatures in their work, despite having never visited any Celtic country. Polish fascination with the far West can be explained partly by general European fashion for Macpherson, Scott, Moore and Villemarqué. However, the complex internal situation in Poland at the time made its writers perceive everything in political terms ${ }^{2}$. It may be that the Polish Romantic cult of a poet as the national bard and prophet owed something to the literature from Celtic countries, but this topic requires further research.

Generally, it was personal interests and earlier studies, and not finances or place of living that influenced some Polish authors' choice to write on Celtic themes (Gmerek 2010). It is possible that we do not yet obtain a fuller picture, for a simple reason that only a few travellers left writings that survived, and also because some archives were destroyed during World War II, while others remain still closed to the public.

Adam Mickiewicz University, Poznań, Poland

\section{References}

Aleksandrowicz, A., 1998, Izabela Czartoryska, Polskość i europejskość [Izabela Czartoryska. A Polish and an European], Lublin: UMCS.

Ampère, J. J., 1839, Histoire littéraire de la France avant le XIIe siècle, t. 1-3, Paris: L. Hachette \& Brockhaus \& Avenarius, 24-97.

Bartkowski, J., 1967, Wspomnienia z powstania 1831 i pierwszych lat emigracji [Recollections of the Polish 1831 Uprising and of the First Years of Emigration], Kraków: Wydawnictwo Literackie, 297-338.

Bridgeman, T. P., 2005, Hyperboreans. Myth and History in Celtic-Hellenic Contacts, New York: Routledge.

Crooker, T. C., 1853, Killarney Legends: Arranged as a Guide to the Lakes, London: Henry G. Bohn.

\footnotetext{
${ }^{2}$ Celtic names and motifs were employed in the nineteenth century literary compositions to disguise some embedded national themes from all sorts of censorship, including Russian, Prussian and Austrian See Gadomski’s Larik (1886) and Konopnicka’s Emmet’s Kiss (Konopnicka 1908).
} 
Czartoryska I., n. d., Tour through England, MS Czart Ew XVII/607, 64-65.

Czartoryska I., n. d., Katalog Domku Gotyckiego [The Gothic House Museum Catalogue], MS Czart. 2917, 106.

Czartoryski, A.J., [n. d.], O rycerstwie [On Knighthood], MS Czart. 6189. IV, 103.

de La Villemarqué, H. T. H., 1842, Pieśni bretońskie [Breton Songs], tr. Siemieński L., Poznań: Walenty Stefański.

Gadomski, J., 1886, Larik, Warszawa.

Gmerek, K., 2007, 'Myrddin Emrys a'r Bardd o Wlad Pwyl' ['Merlin Ambrosius and a Poet from Poland'], tr. Morgan G., in: Y Traethodydd, Ebrill, 116-121.

Gmerek, K., 2010, Polacy i materia celtycka w 19 w. [Polish People and the Celtic Matters in the 19th Century], Poznań: BU UAM.

Gołębiowska, Z., 2000, W kregu Czartoryskich. Wpływy angielskie w Puławach na przetomie XVIII $i$ XIX w. [In the Czartoryskis' circle. English influences in Pulawy at the turn of the eighteenth century], Lublin: UMCS.

Gray, T., 1757, Odes, London.

Hale, A., 2006, 'Language (Revival) Movements in the Celtic Countries. Cornwall', in: Koch J. T., ed., Celtic Culture. A Historical Encyclopaedia, Santa Barbara-Oxford: ABC-Clio, 1105.

Jellenta, C., 1911, Druid Juliusz Stowacki [Juliusz Stowacki the Druid], Brody.

Konopnicka, M., 1915, '04.07.1890' [the date of Mickiewicz's second burial], in: Czubek J., ed., Poezye. Wydanie zupetne, krytyczne [Poems. Full and critical edition], T. 8, Warszawa. (http://www.archive.org/details/ peozyewydzupeene08-konouoft, accessed 4.09.09).

Konopnicka, M., 1908, 'Pocałunek Roberta Emmeta' ['Robert Emmet’s Kiss'], Witeź 1, February.

Koźmian, S. E., 1845, 'Irland, von I. Venedey... ' [review], in: Przeglad Poznański 2, 153.

Koźmian, S. E., n.d., Pamiętniki z lat 1835-1847 [Memoirs 1835-1847], MS PAU Kr 2211.

Koźmian, S. E., 1862, 'O'Connell w więzieniu' ['O’Connell in Prison'], in: Anglia i Polska [Britain and Poland] 2, 2.

L. U. [Ulrich, L.], 1856, 'Karolan' ['O’Carolan'], in: Pokłosie: Zbieranka Literacka na Rzecz Sierot 5, 206-213.

Lach-Szyrma, K., 1829, 'Rzut oka na pierwiastkowe ludy w Europie' ['A Glimpse on Original Inhabitants of Europe'], in: Pamiętnik Warszawski Umiejętności Czystych i Stosowanych.

Lewestam, F.H., 1841, Pierwotne dzieje Polski [The Origins of Poland], Warszawa.

MacKillop, J., 1998, Dictionary of Celtic Mythology, New York.

Moore, T., 1823, 'O’Donohue Mistress’, in: Irish Melodies 1, Paris, 197. 
Niemcewicz, J.U., 1816, Śpiewy historyczne z muzykq i rycinami... [Historical Songs with Music and Drawings...], Warszawa.

Ó hÓgáin, D., 2006, 'Ó Donnchú, Dónal Na nGeimhleach (c.1140-78)’, in: The Lore of Ireland. An Encyclopaedia of Myth, Legend and Romance, Doughcloyne, 395.

Olizarowski, T., 1852, 'Źródła Emrysa' ['Streams of Emrys'], in: Dzieła [Works], 3, 27.

Olizarowski, T., 1857, Dziewice Erinu [Maids of Erin], Paris.

Ręczyński, J., 1854, Rymotwór w dwóch częściach, komiczno-tragiczny [A Twopart Rhymed Tragicomedy], London: Drukarnia Polska.

Roberts, A., \& Fergusson, W. S., 1988, 'Captain George Renczynski. The Polish connection', Foyle and Londonderry College Former Pupils' Association Magazine, March issue.

Sienkiewicz, K., 1953, Dziennik podróży po Anglii [Diary of Sojourn in Great Britain 1820-21], Wrocław: Ossolineum.

Slowacki, J., n. d., 'Genezis from the Spirit' [English version], tr. Chodkiewicz, K. (http://slowacki.chez.com/genesis.htm, accessed 21.08.09).

Słowacki, J., 1915, 'List do J. Bobrowej. Paryż Ponthieu 30. 1845. 18 Styczeń' ['Letter to Mrs. J. Bobrowa. Paris, Ponthieu 18.01.1845'], in: Listy Juliusza Stowackiego [Juliusz Stowacki Letters], Warszawa, 3, 202.

Toland, J., 1747, 'A Specimen of the Critical History of the Celtic Religion and Learning: Containing An Account of the Druids, or the Priests and Judges; of the Vaids, or the Diviners and Physicians; and of the Bards, or the Poets...', in: The Miscellaneous Works..., 2 vols., London.

Wordsworth, W., 1807, 'To a Highland Girl (At Inversneyde, upon Loch Lomond)', in: Poems in Two Volumes, London, 23-27. 